\title{
Influence Fiscal Stress and Regional Financial Performance of Budget Allocation Capital Shopping on Regional Government
}

\author{
Maya Widyana Dewi ${ }^{1}$, Suprihati ${ }^{2}$ \\ Institut Teknologi Bisnis AAS Indonesia ${ }^{1,2}$ \\ \{maya77itbaas@gmail.com¹, suprihati4566@gmail.com²\}
}

\begin{abstract}
This research is aimed at determining the effect of Fiscal Stress and Local Financial Performance to the allocation of Capital Expenditure budget in regencies. The type of data used in this research is secondary data in the form of Realization of Regional Revenue and Expenditure Budget.. The results of the data analysis panel model in this research is the fixed effect model with weighting. Based on the results of the research show that Fiscal Stress, Harmony Expenditure, SiLPA Financing Ratio, and Fiscal Space ratio on last year is significant and simultaneously effect on the allocation of Capital Expenditure budget for current year. Partially, the results show that Expenditure Harmony ratio and SiLPA's Financing ratio last year have a significant effect on the allocation of Capital Expenditure budget for current year. While Fiscal Stress and Fiscal Space ratio on last year have no significant effect on the allocation of Capital Expenditure budget for current year.
\end{abstract}

Keywords:Fiscal Stress, Capital Expenditure, Harmony Expenditure, SiLPA, Fiscal Space

\section{Introduction}

Regional spending on a national scale for 5 years, from 2014 to 2018, is still dominated by personnel expenditure. The total personnel expenditure in all regions increased by an average of 6 percent annually. Staff expenditures account for an average of 37.3 percent annually of total expenditure. Meanwhile, capital expenditures on average only increased by 2.3 percent and took an average portion of 22 percent annually from total overall expenditure. From this portion of expenditure, it can be seen that the tendency of regional spending is still oriented towards spending on public service providers, not on building public facilities.

The province of Central Java in the aggregate province / district / city still allocates a small portion of capital expenditure. The average ratio of capital expenditure to total regional expenditure in 2016 for provincial / district / city aggregates is 24.23 percent and Central Java is the province that has the lowest ratio, which is 16.55. Central Java also occupies the lowest position with a capital expenditure ratio of 7.5\%. This indicates that both in 2016 and 2018, Central Java Province still allocates a small portion of capital expenditure. In terms of allocating capital expenditures, local governments must really adjust to regional needs, taking 
into account the regional revenues received. According to Nuarisa (2013), the size of capital expenditure will be determined by the size of the regional income. So if the regional government wants to increase capital expenditure for public services and improve the welfare of the community, then the regional government must be able to explore the sources of regional revenue as much as possible.

Every region in Indonesia has different financial capabilities in funding spending in their respective regions. For regions that have limited resources, they will certainly experience difficulties in financing their regional spending. Regions that have limited sources of revenue can experience symptoms of higher fiscal stress compared to regions that have large and stable sources of revenue. Muryawan and Sukarsa (2014) state that fiscal stress is a pressure that occurs due to the limited acceptance of budget revenues to local governments to finance development implementation and increase independence in their regions.

The occurrence of fiscal stress can result in the instability of the readiness of district / city governments, especially in terms of finance (Nugroho and Rohman, 2012). And the ability of the region to manage finances is reflected in the performance of regional finances. Some research results indicate that regional financial performance can influence capital expenditure budget allocation decisions. Whether or not the local financial performance can be seen by analyzing the financial ratio of the regional budget. Common financial ratios used to measure regional financial performance include independence ratios, dependency ratios, effectiveness ratios, efficiency ratios, profit contribution ratios, expenditure effectiveness ratios, expenditure harmony ratios, debt service coverage ratio, level ratios SiLPA financing, fiscal space ratio, etc. In this research, financial performance measures will focus on the ratio of expenditure harmony, ratio of SiLPA financing level, and fiscal space ratio.

\section{Theoretical Review}

Fiscal stressindefine it as budgetary pressures that occur as a result of limited local revenue that can have a significant influence on the delivery of public services, where financial pressure is getting higher due to demands for increased independence aimed at increasing own revenues to finance various existing expenditure (Arnett, 2012). In this study, to measure regional financial performance, financial performance ratios are used, including the ratio of expenditure harmony, the ratio of SiLPA financing levels, and the ratio of fiscal space.

The ratio of expenditure harmonization illustrates how regional governments prioritize the allocation of funds to routine expenditure (operating expenditure) and development spending (capital expenditure) optimally. Dora (2017), there are 2 calculations in the matching ratio, namely: the ratio of operating expenditure and the ratio of capital expenditure. This ratio informs the reader of the report about the portion of regional expenditure allocated to operating expenditure. Operating expenses are expenditures whose benefits are consumed in one fiscal year, so that they are short-term and in some cases routine or recurring. The operating expenditure component consists of employee expenditure, goods and services expenditure, interest expenditure, subsidy expenditure, grant expenditure, and social assistance expenditure. Capital expenditure ratio is a comparison between total capital expenditure and total regional expenditure allocated for investment in the form of capital expenditure. The nature of capital expenditure is the addition of fixed assets that have medium and long term benefits. Besides capital expenditure is also not routine.

The SiLPA financing level ratio is a financial ratio calculated by comparing SiLPA with 
last year's total expenditure. The SiLPA ratio to expenditure shows the portion of pending expenditure or the budget that is not absorbed and illustrates the amount of revenue realization in the previous fiscal year greater than the projected (Ratna, 2019).

Fiscal space ratio reflects how much discretion (discretion) a regional government has in using its funds freely in determining spending priorities. The calculation of fiscal space uses a formula issued by the Ministry of Finance, where the total regional income is reduced by grant income; earmarked income, namely the Special Allocation Fund (DAK), the Special Autonomy Fund and the Adjustment Fund and Emergency Fund; and expenditure which is binding in nature, namely Employee Expenditures and Interest Expenditures and subsequently divided by overall Regional Revenue. According to Government Regulation (PP) Number 71 of 2010 concerning Accounting Standards

Government, "Capital expenditure is a budget expenditure for the acquisition of fixed assets and other assets that provide benefits more than one accounting period. Capital expenditures include capital expenditures for the acquisition of land, buildings and buildings, equipment, intangible assets. Based on Government Accounting Standards Statement No. 01, the budget is defined as "a guideline for action to be carried out by the government including revenue, expenditure, transfer and financing plans measured in rupiah, arranged according to a certain classification systematically for one period". Meanwhile, in the opinion of Bastian (2010: 19), the budget is defined as "a package of statements concerning estimates of revenues and expenditures that are expected to occur in one or several future periods. The budget always includes data on revenues and expenses that occurred in the past ".

\subsection{Effect of Fiscal Stress on the Capital Expenditure Budget Allocation}

Not all autonomous regions in Indonesia have the same financial capabilities. For regions that have adequate potential and resources, they will be ready to implement fiscal decentralization because they have the ability to increase revenues and meet their spending needs. As for regions that are unable to achieve these conditions, they will experience fiscal stress. Muryawan and Sukarsa (2014) state that fiscal stress is a pressure that occurs due to the limited revenue received by local governments to finance the implementation of development and increase independence in their regions. Amalia (2013) in her research places fiscal stress as a variable that influences the allocation of capital expenditure. The results of his research indicate that fiscal stress has a positive and direct effect on capital expenditure. Huda (2015) in his research explained that in regions that experience fiscal stress will increase the allocation of capital expenditure in an effort to continue to increase regional income. The results of his research showed that last year's fiscal stress had a significant effect on the allocation of capital expenditure the following year. H1: Fiscal Stress of the previous year has a significant effect on budget allocation Belanja The current year's capital.

\subsection{The Effect of the Ratio of Expenditure Harmony to the Allocation of Capital Expenditure Budget}

The ratio of expenditure harmony in this study is used to find out the description of the use of APBD funds allocated by local governments for routine expenditure (operating expenditure) and development expenditure (capital expenditure). What is the priority scale of regional government spending for one fiscal year can be seen from the ratio of expenditure harmony. This ratio is also called the activity ratio, the calculation of which can be done using 2 (two) ratios, namely the ratio of operating expenditure to overall regional expenditure and 
the ratio of capital expenditure to overall regional expenditure. Through this ratio, the report reader can find out what portion of regional expenditure is allocated to operating expenditure and what portion is allocated to capital expenditure in the relevant fiscal year. Based on research conducted by Assyurriani (2015) and Kurniawan and Arza (2019) shows that the ratio of expenditure harmony has a positive and significant effect on the allocation of capital expenditure. These results are different from research conducted by Afriliani (2016) and Jayanti (2017) where the ratio of expenditure harmony has a significant effect on the allocation of capital expenditure in a negative direction. H2: Previous year's Expenditures Ratio has a significant effect on the allocation of the current year's Capital Expenditure budget.

\subsection{Effects of the SiLPA Financing Rate Ratio on the Allocation of the Capital Expenditure Budget}

The Remaining Budget Calculation (SiLPA) is the remaining funds in the previous year's budget which were formed due to a surplus (excess) in the APBD where the realization of regional income is greater than the regional expenditure. SiLPA is basically sourced from exceeding income or spending savings on the realization of the regional budget which in the following year can be used as an alternative source of regional funding. In this regard, the size of the previous year's SiLPA can certainly be one source of funding in the following year to fund productive regional expenditures, such as capital expenditure. To know the contribution of the previous year's remaining budget in funding regional expenditure the following year, the SiLPA financing ratio is used. Hidayat (2013) in his research stated that the SiLPA financing ratio positively contributed to the increase in capital expenditure allocations. The greater the ratio of the previous year's SiLPA financing level, the greater the capital expenditure allocation in the following year. These results are in line with research conducted by Fakhry (2017) which proves that the ratio of the previous year's SiLPA financing level has a positive and significant effect on the current year's capital expenditure allocation. While the different results are shown by Martini and Dwirandra's research (2015) which states that the ratio of the level of SiLPA financing has a negative and significant effect on the allocation of capital expenditure. In the same year, Huda (2015) in his research proved that the ratio of the previous year's SiLPA financing did not significantly influence the current year's capital expenditure allocation. H3: The ratio of the previous year's SiLPA Financing Rate has a significant effect on the allocation of the current year's Capital Expenditure budget.

\subsection{Effects of the Fiscal Space Ratio on the Allocation of the Capital Expenditure Budget}

Fiscal money shows the flexibility of regional governments in using their own funds after deducting their intended use. In other words, fiscal space creates a free fund or flexible fund in a government budget after the planned government expenditure is specified and used. The amount of the flexible fund is based on earmarked income and mandatory spending such as employee and interest expenditure. With fiscal space, local governments have flexible funds that can be used to finance activities that are regional priorities. Hidayat's research (2013) states that last year's fiscal space ratio had a positive and significant effect on the allocation of capital expenditure the following year. The same results were also shown by the research of Huda (2015) and Martini and Dwirandra (2015) which proved that the fiscal space ratio has a positive and significant effect on the allocation of capital expenditure. Whereas in Fakhry's 
research (2017), last year's fiscal space ratio was not proven to have a significant effect on the allocation of capital expenditure the following year. H4: The previous year's Fiscal Space Ratio has a significant effect on the allocation of the current year's Capital Expenditure budget.

\subsection{Effects of Fiscal Stress, Spending Match Ratio, SiLPA Financing Rate Ratio, and Simultaneous Fiscal Space Ratio on Capital Budget Allocation}

Capital expenditure is expenditure or budget allocation in order to obtain fixed assets that benefit more than one accounting period. Several previous studies have shown that the allocation of capital expenditure by local governments can be influenced by fiscal stress and regional financial performance. Research conducted by Amalia (2013) and Huda (2015) shows that fiscal stress influences the allocation of capital expenditure. Another study was conducted by Hidayat (2013) who examined the effect of regional financial performance on capital expenditure allocations. The results of his research showed that the performance of regional finances last year had a significant effect on the allocation of capital expenditure the following year, in particular the ratio of SiLPA financing levels and the ratio of fiscal space. In addition to the two ratios, capital expenditure allocation is also influenced by the ratio of expenditure harmony. The results of previous studies indicate that the ratio of expenditure harmony has an influence on the allocation of capital expenditure, including research conducted by Afriliani (2016) and Jayanti (2017). H5: Previous year's Fiscal Stress, Previous year's Expenditures Spending Ratio, Previous year's SiLPA Financing Ratio, and Previous year's Fiscal Space Ratio have a joint effect on the allocation of the current year's Capital Expenditure budget.

\section{Research Method}

The population used in this study were all regencies and cities in Central Java Province which consisted of 29 regencies and 6 cities. The data used are secondary data in the form of budget data and the realization of the district / city revenue and expenditure (APBD) in the Central Java Province obtained or downloaded from the Ministry of Finance's DJPK website. The determination of the sample in this study uses a saturated sampling technique, where all members of the population are used as samples. The samples taken are all regencies and cities in Central Java Province with the observation period starting in 2015 until 2019. So the total number of samples studied was 175 samples.

\section{Result}

Table 1. Descriptive Statistics Analysis

\begin{tabular}{lrrrrr}
\hline & ABM & FS & RKB & RPS & RRF \\
\hline The mean & 0.1684 & 0.1693 & 0.7089 & 0.1708 & 0.3196 \\
Maximum & .3676 & 0.4139 & 0.8752 & 0.9066 & 0.8552 \\
Minimum & 0.0533 & 0.0878 & 0.5458 & 0.022 & 0.1316 \\
Std. Deviation & 0.0475 & 0.0594 & 0.0761 & 0.1236 & 0.0974 \\
Observations & 175 & 175 & 175 & 175 & 175 \\
\hline
\end{tabular}


Shows that the number of observations was 175, obtained from the time series multiplication of 5 years and the number of cross sections during the observation period were 35 regencies / cities in Central Java Province. Based on descriptive statistics of the variables used in this research modeling, the descriptive analysis of each variable will be explained as follows:

The Capital Expenditure Budget Allocation shows that the average allocation for the capital expenditure budget in the district / city government in Central Java Province in five years (2015-2019) is 0.1684 or 16.84 percent. The regional government with the highest capital expenditure budget allocation value is Semarang City in 2019 amounting to 0.3676 or 36.76 percent. Whereas the regional government with the lowest capital expenditure budget allocation is Pemalang Regency in 2016. Pemalang Regency only allocates a capital expenditure budget of 0.0533 or 5.33 percent of the total regional expenditure budget. In the 2014-2018 period, Fiscal Stress as measured by the amount of realized local revenue (PAD) compared to the realization of total regional expenditure showed an average value of 0.1693 or 16.93 percent with a standard deviation value of 0.0594 or 5, 94 percent. The district / city government with the highest fiscal stress value owned by Semarang City in 2017 was 0.4139 or 41.39 percent. While the lowest fiscal stress was owned by Blora Regency in 2016 amounting to 0.0878 or 8.78 percent.

The Spending Harmony ratio in the 2014-2018 period shows an average value of 0.7089 or 70.89 percent with a standard deviation of 0.0761 or 7.61 percent. Tegal City has the highest expenditure harmony ratio in 2018 of 0.8752 . This means that Tegal City regional government operational expenditure dominates total regional expenditure of 87.52 percent. While the lowest value of the ratio of expenditure harmony is owned by Demaks Regency as much as 0.5458 or 54.58 percent in 2016 .

SiLPA Financing Rate ratio in the period 2014-2018 shows an average value of 0.1708 or 17.08 percent with a standard deviation of 0.1236 or 12.36 percent. The regional government with the highest SiLPA ratio of the previous fiscal year to total expenditure was Salatiga City in 2015 which was 0.9066 or 90.66 percent. While the lowest value is owned by Blora Regency in 2017 that is equal to 0.0220 or 2.20 percent.

Fiscal Space ratio in the period 2014-2018 shows an average value of 0.3196 or 31.96 percent with a standard deviation of 0.0974 or 9.74 percent. The highest Fiscal Space Ratio is owned by Batang Regency in 2017 of 0.8552 or 85.52 percent. While the lowest value of the fiscal space ratio owned by Purworejo Regency in 2015 was 0.1316 or 13.16 percent.

The decision to choose and determine the panel data regression model is based on three stages of testing, namely the Chow Test, the Hausman Test, and the Lagrange Multiplier (LM) Test. The Chow Test is used to decide whether to use the common effect or fixed effect model. Then use the Hausman test to choose whether the fixed effect or random effect model is the most appropriate. And the third test, the Lagrange Multiplier (LM) test is used to choose between the common effect model or the random effect model.

Table 2. Chow Test Results

\begin{tabular}{ccc}
\hline Test Effect & Statistics & Prob \\
\hline Cross-section F & 3,723173 & 0 \\
\hline
\end{tabular}

The results of processing the Chow test in the table above shows that the value of the cross-section probability $\mathrm{F}$ is 0.0000 . The cross-section probability value of $\mathrm{F}$ is 0.0000 less than the significance value $5 \%(0.0000<0.05)$, so statistically the decision in the Chow test is rejecting $\mathrm{H} 0$. Thus, the temporary decision of the chosen model is the fixed effect model. So 
the model must be treated by cross-section weights. After weighting with cross-section weights, the next stage of analysis is to compare the fixed effect model without weighting with the fixed effect model that is weighted (cross-section weights). The results of the comparison can be used as an assessment to determine the best model between fixed effects or fixed effect cross-section weights. Here is a comparison of the two models:

Table 3. Hausman Test Results

\begin{tabular}{ccc}
\hline Summary Test & Chi-Sq Statistics & Prob \\
\hline Random cross section & 10,31694 & 0.0354 \\
\hline
\end{tabular}

The results of the Hausman test processing in the table above show that the Chi-Square probability value shows a value of 0.0354 . This value is smaller than the significance value of $5 \%(0.0354<0.05)$, so that statistically $\mathrm{H} 0$ is rejected and it means that the most appropriate model used according to the Hausman test is the fixed effect model. From the normality test results obtained by the Jarque-Bera value of 1.643109 with a probability value of 0.439747 . Probability value 0.439747 is greater than the significance level of $0.05(0.439747>0.05)$ so it can be concluded that the model in this study is normally distributed. The following is a summary table of multicollinearity test results seen from the correlation coefficient:

Table 4. Multicollinearity Test Results

\begin{tabular}{lrrrr}
\hline \multicolumn{1}{c}{ FS } & \multicolumn{1}{c}{ RKB } & \multicolumn{1}{c}{ RPS } & \multicolumn{1}{c}{ RRF } \\
\hline FS & 1 & 0.300024 & 0.21243 & 0.577285 \\
RKB & 0.300024 & 1 & 0.305047 & -0.063617 \\
RPS & 0.21243 & 0.305047 & 1 & $-0,027736$ \\
RRF & 0.577285 & -0.063617 & $-0,027736$ & 1 \\
\hline
\end{tabular}

Based on the table above, it can be seen that there is no correlation coefficient between independent variables that shows a value of more than 0.8 . So it can be concluded that there is no multicollinearity problem in the regression model of this study.

Table 5. Panel Data Regression Test Results

\begin{tabular}{lrrrr}
\hline Variable & Coefficient & Std. Error & t-Statistics & \multicolumn{1}{c}{ Prob } \\
\hline C & 0.271781 & 0.029295 & 9,277493 & 0 \\
FS & 0.036696 & 0.124171 & 0.29553 & 0.768 \\
RKB & $-0,179465$ & 0.030477 & $-5,88853$ & 0 \\
RPS & 0.090149 & 0.019403 & 4,646165 & 0 \\
RRF & 0.00701 & 0.043065 & 0.162777 & 0.8709 \\
\hline
\end{tabular}

Based on the results of panel data analysis, an appropriate regression model is obtained, namely the fixed effect cross-section weights model with the following regression equation:

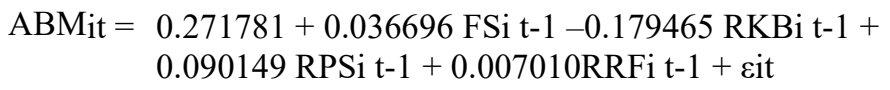

Table 6. Heteroscedasticity Test Results

\begin{tabular}{ccc}
\hline & $\begin{array}{c}\text { Weighted } \\
\text { Statistics }\end{array}$ & $\begin{array}{c}\text { Unweighted } \\
\text { Statistics }\end{array}$ \\
\hline Sum squared resid & 0.124193 & 0.125529 \\
\hline
\end{tabular}


By looking at the sum squared residual weighted statistic value of 0.124193 which is smaller than the sum squared residual unweighted statistic value of 0.125529 , it can be concluded that the model contains a heteroscedasticity problem where the variance of each element of error is not constant. However, by doing cross-section weights on this research model, the problem has been resolved and the estimation model can be said to be free from the problem of heteroscedasticity.

\begin{tabular}{clrrlr}
\multicolumn{7}{c}{ Table 7. t-Test Results } \\
\hline No & \multicolumn{1}{c}{ City } & $\mathbf{C}+\mathbf{C i}$ & No & \multicolumn{1}{c}{ City } & $\mathbf{C}+\mathbf{C i}$ \\
\hline 1 & Semarang & 0,389782 & 19 & Purbalingga & 0,267092 \\
2 & Pekalongan & 0,319115 & 20 & Sukoharjo & 0,265951 \\
3 & Magelang & 0,316102 & 21 & Magelang & 0,26271 \\
4 & Surakarta & 0,307675 & 22 & Kebumen & 0,261675 \\
5 & Salatiga & 0,304932 & 23 & Wonosobo & 0,260902 \\
6 & Tegal & 0,297011 & 24 & Rembang & 0,257475 \\
7 & Wonogiri & 0,294078 & 25 & Semarang & 0,254686 \\
8 & Demak & 0,29393 & 26 & Batang & 0,24792 \\
9 & Boyolali & 0,291859 & 27 & Jepara & 0,243368 \\
10 & Tegal & 0,290139 & 28 & Kendal & 0,241525 \\
11 & Blora & 0,289587 & 29 & Pemalang & 0,241193 \\
12 & Cilacap & 0,286282 & 30 & Sragen & 0,240389 \\
13 & Temanggung & 0,283785 & 31 & Banyumas & 0,240045 \\
14 & Kudus & 0,283112 & 32 & Purworejo & 0,23808 \\
15 & Banjarnegara & 0,280423 & 33 & Karanganyar & 0,227004 \\
16 & Pekalongan & 0,278845 & 34 & Pati & 0,209526 \\
17 & Brebes & 0,271695 & 35 & Klaten & 0,203465 \\
18 & Grobogan & 0,270977 & & & \\
\hline
\end{tabular}

The first hypothesis testing regarding the influence of the fiscal stress variable of the previous year the allocation of the current year's capital expenditure budget shows a t-value of 0.295530 with a probability value of 0.7680 . Because the value of t-count is smaller than the value of t-table $(0.295530<1.65387)$ and the probability value is greater than the significance level of $0.05(0.7680>0.05)$, it can be concluded that the fiscal stresstthe previous year had a positive and not significant effect on the current year's capital expenditure budget allocation. Thus, this study explains that the first hypothesis (H1) is rejected.

The second hypothesis testing regarding the effect of the variable ratio of the previous year's expenditure harmony to the allocation of the current year's capital expenditure budget shows a calculated value of -5.888530 with a probability value of 0.0000 . Because the t-value is greater than the t-table value $(5.888530>1.65387)$ and is negative, while the probability value is less than the significance level of $0.05(0.0000<0.05)$, it can be concluded that the ratio variable Previous year's expenditure harmony had a negative and significant effect on the current year's capital expenditure budget allocation.Thus, this study explains that the second hypothesis (H2) is accepted.

The third hypothesis testing regarding the influence of SiLPA financing level ratio of the previous year on the allocation of the current year's capital expenditure budget shows a t-value of 4.646165 with a probability value of 0.0000 . Based on the t-value greater than the t-table value $(4.646165>1.65387)$ and the probability value that is smaller than the significance level $(0.0000<0.05)$, it can be concluded that the variable ratio of the SiLPA financing level for the year previously had a positive and significant effect on the allocation of the current year's capital expenditure budget. Thus, this study supports the third hypothesis so that the third 
hypothesis (H3) is accepted.

Testing the fourth hypothesis regarding the influence of the fiscal space ratio variable of the previous year on the allocation of the current year's capital expenditure budget shows a calculated value of 0.162777 with a probability value of 0.8709 . T-value smaller than the ttable value $(0.162777<1.65387)$ and a probability value greater than the 0.05 significance level $(0.8709>0.05)$ indicates that the fiscal space ratio variable in the previous year has a positive and not significant effect on the allocation of the current year's capital expenditure budget. Thus, this study explains that the fourth hypothesis (H4) is rejected.

Table 8. Test Model suitability

\begin{tabular}{cc}
\hline & Weighted Statistics \\
\hline F-statistics & 12,73832 \\
Prob (F-statistic) & 0 \\
\hline
\end{tabular}

Based on the above table, the calculated F-value is 12.73832 with a probability value of 0.000000 . The results show that the F-calculated value is greater than the F-table value $(12.73832>2.42)$ and the F-calculated probability value is smaller than the significance level of $0.05(0.00000000)<0.05)$ so that it can be concluded that all independent variables simultaneously have a significant effect on the allocation of the current year's capital expenditure budget. Thus, this study explains that the fifth hypothesis (H5) is accepted.

Table 9. Determination Test Results

\begin{tabular}{cc}
\multicolumn{2}{c}{ Table 9. Determination Test Results } \\
\hline Weighted Statistics \\
\hline R-squared & 0.780665 \\
Adjusted R-squared & 0.71938 \\
\hline
\end{tabular}

The result of the adjusted R-squared in the table above is 0.719380 which means that the fiscal stress variable of the previous year, the ratio of expenditure harmony in the previous year, the ratio of the level of SiLPA financing in the previous year, and the fiscal space ratio of the previous year had a contributing influence on the variable budget allocation current year's capital expenditure of 71.94 percent, while the remaining 28.06 percent is influenced by other factors outside the independent variable in this study.

\section{a) The Influence of Previous Year's Fiscal Stress on the Allocation of the Current Year's Capital Expenditure Budget}

The partial test results from the fixed effect cross-section weights model show that the fiscal stress of the previous year did not significantly influence the capital expenditure budget allocation the year is running with a positive value. This indicates that if the fiscal stress of the previous year had increased, the current year's capital expenditure budget allocation had also increased, but the increase was not significant enough.

The influence of fiscal stress in the previous year which is insignificant to the current year's capital expenditure budget allocation suggests that the high and low level of fiscal stress in the previous year was not enough to motivate the local government to increase the allocation of capital expenditure budget the following year. In a fiscal stress condition, local governments are required to optimize their regional revenues (local own revenue) to meet regional spending and reduce dependency from the central government. So that the regional governments that experience fiscal stress should be more motivated to increase capital expenditure in an effort to get reciprocity in the form of local revenue 
On the results of a descriptive analysis that had been done previously obtained an average value of fiscal stress of the district / city government in Central Java province of 16.93 percent. This indicates that almost all regions in Central Java Province experienced fiscal stress as reflected by the contribution of regional own-source revenue (PAD) to regional spending by only 16.93 percent. In this case, the role of regional own-source revenue (PAD) as a source of funding for expenditure is still low because more than 50 percent of the regional expenditure component can still be funded from other sources of income outside of PAD. Thus, if the PAD is low then the local government will depend on balance funds from the central government and other legitimate regional revenues.

Kurniawan and Arza (2019) in their research explained that if the regional government experiences fiscal stress (fiscal stress) then the regional government will maximize the allocation of balance funds received from the central government. As a source of regional revenue, the balance fund still contributes greatly in funding regional expenditure, including capital expenditure. This means that the decision to allocate capital expenditure in the regional budget can rely on the allocation of balance funds from the central government. Based on the explanation above, it can be concluded that the fiscal stress of the previous year had no significant effect on the allocation of the next year's capital expenditure budget. This can be explained that by looking at the fiscal stress condition of the previous year, then the regional government will not fully rely on PAD as a source of funds for capital expenditure allocations. The capital expenditure budget allocation can still be supported by other receipts obtained by a region in the current year's budget, including the receipt of balance funds and other legitimate regional revenues. Thus, the fiscal stress of the previous year did not affect the allocation of capital expenditure budget for the following year. The results of this study are not in line with research conducted by Amalia (2013) and Huda (2015) which states that last year's fiscal stress had a positive and significant effect on the current year's capital expenditure allocation. The capital expenditure budget allocation can still be supported by other receipts obtained by a region in the current year's budget, including the receipt of balance funds and other legitimate regional revenues. Thus, the fiscal stress of the previous year did not affect the allocation of capital expenditure budget for the following year. The results of this study are not in line with research conducted by Amalia (2013) and Huda (2015) which states that last year's fiscal stress had a positive and significant effect on the current year's capital expenditure allocation. The capital expenditure budget allocation can still be supported by other receipts obtained by a region in the current year's budget, including the receipt of balance funds and other legitimate regional revenues. Thus, the fiscal stress of the previous year did not affect the allocation of capital expenditure budget for the following year.

The results of this study are not in line with research conducted by Amalia (2013) and Huda (2015) which states that last year's fiscal stress had a positive and significant effect on the current year's capital expenditure allocation. The fiscal stress of the previous year has no effect on the allocation of capital expenditure budget for the following year. The results of this study are not in line with research conducted by Amalia (2013) and Huda (2015) which states that last year's fiscal stress had a positive and significant effect on the current year's capital expenditure allocation. The fiscal stress of the previous year had no effect on the allocation of the capital expenditure budget for the following year. The results of this study are not in line with research conducted by Amalia (2013) and Huda (2015) which states that last year's fiscal stress had a positive and significant effect on the current year's capital expenditure allocation. 


\section{b) The Effect of the Previous Year's Expenditures Ratio on the Allocation of the Current Year's Capital Expenditure Budget}

The partial test results from the fixed effect cross-section weights model show that the previous year's expenditure harmony ratio had a negative and significant effect on the allocation of the current year's capital expenditure budget. This means that if the previous year's expenditure harmony ratio increases, it will reduce the current year's capital expenditure budget allocation and if the previous year's expenditure harmony ratio decreases, the current year's capital expenditure budget allocation will increase.

The ratio of expenditure harmony in this study is measured using the ratio of operating expenditure to total regional expenditure. Operating expenses are budget expenditures that are used for daily activities of local governments and provide short-term benefits. Spending operations have a character that is standard and standardized where the use of items is difficult to change (Karlinda, 2015). This expenditure includes employee expenditure, goods and services expenditure, interest expenditure, subsidy expenditure, grant expenditure, and social assistance expenditure. During the 2014 period - 2018, the average ratio of operating expenditure to total regional expenditure is 70.89 percent. This indicates that operating expenditure still dominates overall regional expenditure where more than 50 percent of expenditure is allocated for operating expenditure. While expenditure intended for capital expenditures obtained an average value of 18.34 percent of total regional expenditure.

The researcher suspects that there is a significant influence between the ratio of the harmony of the previous year's expenditure to the allocation of the current year's capital expenditure budget due to the initial budgeting process that is still not in accordance with the theory of performance-based budgeting. In the budget preparation process there is a budgeting system known as incremental budgeting, which is a budgeting method that is based on budget allocation figures or budget realization in the previous year. By reflecting on the allocation of the previous year's budget, the regional government can determine the amount of the budget intended for next year's expenditure needs. If the basic calculation of operating expenditure needs uses data years prior to the planned fiscal year, then this also has an impact on the allocation of capital expenditure budget in the same year. Unlike the incremental budgeting system, in a performance-based budgeting system, the budgeting process should be based on the budgetary needs of each program and activity that is reflected in the outputs. The results of this study are consistent with the research of Afriliani (2016) and Jayanti (2017), which proves that the ratio of expenditure harmony has a negative and significant effect on the allocation of capital expenditure.

c) The Influence of Silpa Financing Ratio for the Previous Year on the Allocation of the Current Year's Capital Expenditure Budget

The partial test results from the fixed effect cross-section weights model show that the ratio of the previous year's SiLPA financing level had a significant and positive effect on the allocation of the current year's capital expenditure budget. A positive effect indicates that if the ratio of the previous year's SiLPA financing level has increased, the capital expenditure budget allocation will also increase.

The positive and significant influence of the ratio of SiLPA financing levels to the allocation of capital expenditure indicates that the previous year's SiLPA will be used by local governments to increase the capital expenditure budget allocation in the current year. The contribution of SiLPA as additional funding to the APBD is proven to be earmarked for 
funding productive regional expenditure, such as capital expenditure. The results of this study are relevant to previous research conducted by Hidayat (2013) and Fakhry (2017) which proves that the ratio of the previous year's SiLPA financing level had a positive and significant effect on the current year's capital expenditure allocation.

\section{d) Effect of Fiscal Space Ratio in the Previous Year on the Allocation of the Current Year's Capital Expenditure Budget}

The partial test results from the fixed effect cross-section weights model show that the fiscal space ratio of the previous year had no significant effect on the allocation of the current year's capital expenditure budget. This insignificant influence indicates that the size of the fiscal space owned by the regional government in the previous year did not sufficiently influence the regional government in increasing the capital expenditure budget allocation for the current year. Regional governments in using their funds freely for shopping needs that are a priority for the region. If you look at the results of a descriptive analysis that has been done before, an average value of the fiscal space of the district / city government in Central Java Province is 32 percent of total revenue. This can be interpreted that there is a free fund of 32 percent of the total revenue that can be utilized by local governments to fund programs / activities accordingly outside regional spending which is binding (employee expenditure and interest expenditure). From the average size of the fiscal space it can be explained that almost all regions in Central Java province still have limited fiscal space. The greater fiscal space owned by local governments basically shows the increasing amount of funds that can still be used freely by local governments.

If you look at the composition of regional expenditure, the component of operating expenditure still dominates capital expenditure. This allows fiscal space to be unaffected by capital expenditure budget allocation because most of the free funds are still used by regional governments to fund operational expenditure needs. Hidayat (2013) in his research argues that last year's fiscal space should be used as a benchmark for designing the next fiscal year so that through this fiscal space the government can plan expenditure allocations, especially capital expenditure in accordance with regional development priorities. The results of this study are in line with the results of Fakhry's research (2017) which proves that the fiscal space ratio of the previous year had no significant effect on the current year's capital expenditure allocation.

\section{Conclusion}

Fiscal Stresstidak significant and positive effect on the allocation of the Capital Expenditure Budget. This can be explained that by looking at the fiscal stress condition of the previous year, the regional government.The performance of Regional Finance as measured by the Ratio of Spending Harmony has a significant and negative effect on the allocation of the Capital Expenditure Budget. If the calculation of operating expenditure needs for the current year is based on the previous year's budget allocation, of course this will impact on the capital expenditure budget allocation in the same year. Regional Financial Performance as measured by the SiLPA Financing Rate Ratio has a significant and positive effect on the allocation of the Capital Expenditure Budget. The significant influence of the ratio of SiLPA financing levels to the allocation of capital expenditure indicates that the previous year's significant amount of SiLPA by regional governments to increase the allocation of capital expenditure budget in the current year. The performance of Regional Finance as measured by the Fiscal 
Space Ratio has no significant and positive effect on the allocation of the Capital Expenditure Budget. This ratio does not have a large influence on the allocation of capital expenditure budget because most of the available free funds are still allocated by regional governments to fund operational expenditure needs.

\section{References}

[1] Anisa, Nuralifmida Ayu. (2012). Pengaruh Corporate Governance Terhadap Tax avoidance. Jurnal Akuntansi dan Auditing. Vol. 8 No. 2 Mei 2012 hal 95-189.

[2] Afriliani .2016.Belanja Pada Pemerintah Daerah (Studi Empiris Pada Pemerintah Daerah Kabupaten/Kota di Provinsi Sumatera Barat. Jurnal Eksplorasi Akuntansi 1(3): 1275-1292.

[3] Arnett, Sarah B. 2012. Fiscal Stress in the U. S. States: An Analysis of Measures and Responses. Georgia State University

[4] Assyurriani, Raja. 2015. Pengaruh Rasio Kemandirian Daerah, Rasio Efektivitas, Rasio Efesiensi, Rasio Aktivitas dan Rasio Pertumbuhan Terhadap Belanja Modal Pada Pemerintah Kabupaten Dan Pemerintah Kota Di Kepulauan Riau Tahun 2010 - 2013. Jurnal Akuntansi.

[5] Bastian, Indra. 2010. Akuntansi Sektor Publik Suatu Pengantar Edisi Ketiga. Penerbit Erlangga. Jakarta

[6] Direktorat Jenderal Perimbangan Keuangan (DJPK).. 2016. Ringkasan APBD 2016. Kementerian Keuangan Republik Indonesia.

[7] Hidayat, Mochamad Fajar. 2013. Analisis Pengaruh Kinerja Keuangan Daerah Terhadap Alokasi Belanja Modal (Studi pada Kabupaten dan Kota di Jawa Timur)". Jurnal Ilmiah Mahasiswa FEB, 1 (2).

[8] Huda, Ahmad Syahral. 2015. Pengaruh Kinerja Keuangan, Fiscal Stress, dan Kepadatan Penduduk Terhadap Alokasi Belanja Modal di Nusa Tenggara Barat. Assets 5 No.2: 151-66.

[9] Karlinda, Elizabeth. 2015. Optimalisasi Fiskal Bagi Pertumbuhan Ekonomi Daerah: Peran Belanja Operasional dan Belanja Modal dalam APBD.

[10] Kurniawan, Arief, dan Fefri Indra Arza. 2019. Pengaruh Fiscal Stress, Varians Anggaran danPerubahan Sisa Lebih Perhitungan Anggaran Terhadap Perubahan Anggaran

[11] Mangkuwinata, Sonny Muhammad Ikhsan. 2018. Pengaruh Fiscal Stress Terhadap Belanja Modal Kabupaten Bireuen”. Jurnal Ekonomika 9 (17).

[12] Martini, Kadek, dan A.A.N.B. Dwirandra. 2015. Pengaruh Kinerja Keuangan Daerah

[13] Muryawan, Sang, dan Made Sukarsa. 2014. Pengaruh Desentralisasi Fiskal, Fiscal Stress, dan Kinerja Keuangan Daerah Terhadap Pertumbuhan Ekonomi di Kabupaten/Kota Provinsi Bali. E-Jurnal Ekonomi Pembangunan Universitas Udayana 3 (10): 440-51.

[14] Nuarisa, Sheila Ardhian. 2013. Pengaruh PAD, DAU dan DAK terhadap Pengalokasian Anggaran Belanja Modal. Accounting Analysis Journal 2 (1).

[15] Nugroho, Fajar, dan Abdul Rohman. 2012. Pengaruh Belanja Modal Terhadap Pertumbuhan Kinerja Keuangan Daerah Dengan Pendapatan Asli Daerah Sebagai Variabel Intervening. Diponegoro Journal Of Accountin 1 (2): 1-14.

[16] Ratna, Ikhwani. 2018. Faktor-Faktor Yang Mempengaruhi Jumlah Sisa Lebih 
Perhitungan Anggaran (SiLPA) Anggaran Pendapatan dan Belanja Daerah Pada Pemerintah Provinsi Riau. Jurnal EL-RIYASAH 9 (1).

[17] Republik Indonesia. 2004. Undang-Undang Nomor 32 Tahun 2004 Tentang Pemerintah Daerah.

[18] Sugiyono. 2016. Metodologi Penelitian Kuantitatif, Kualitatif, dan R\&D. CV Alfabeta. Bandung

[19] Widarjono, Agus. 2018. Ekonometrika Pengantar Dan Aplikasinya Disertai Panduan Eviews Edisi 5. UPP STIM YKPN .Yogyakarta. 